\title{
FOUR NEW HELMID $\$$ FROM CUBA, WITH NOTES ON OTHER WEST INDIAN SPECIES ${ }^{1}$
}

\author{
By P. J. Darlington, Jr.
}

In common with all but the most thoroughly worked parts of the world the West Indies have yielded to entomological collections only a very small fraction of their probable Helmid fauna, indeed only one species of the family is at present recorded from that entire series of islands. It was with particular pleasure, therefore, that four apparently undescribed species of Helmis were collected during the eight weeks which I was privileged to spend, during the fall of 1926, at the Harvard Biological Laboratory on the Soledad sugar "central", near Cienfuegos, southern Santa Clara, Cuba. The genus was first noted on Oct. 19, when two specimens were taken on a stone secured from the bed of the Arimao River. The same locality was visited again on Dec. 3, and two hours of back-breaking work in from six to eighteen inches of swiftly flowing water, just above the point where the current broke into a series of minor rapids, yielded twenty-nine specimens, including all the species obtained. Finally, a single specimen was discovered in going over alcoholic material collected Nov. 24, along a gravel bar of one of the larger tributaries of the Arimao.

These species have definite affinities with others occuring in the southern United States, notably in Texas, but all have equally definite distinguishing characters of specific value. As far as I can judge from the descriptions and plates in "Biologia," none of the described Mexican and Central American species are very closely allied to the Cuban ones, a finding which is in agreement with the general conclusions reached by Leng and Mutchler in their preliminary list of West Indian Coleoptera. In order to establish relationships, specimens or descriptions of all the species listed from America north of Mexico by Mr. Leng have been examined.

The Cuban species are only moderately closely related

${ }^{1}$ Contributions from the Entomological Laboratory of the Bussey Institution, Harvard University, No. 283. 
among themselves, but are mutually congeneric according to the characters in use at present. There is considerable variation in the width of the prosternum between the coxæ, but this seems to have no generic value, and is often at least partly due to superficial lateral dilation of the sternum over the edge of the coxa rather than to a change in the insertion of the latter. In Helmis simplex, here described, which has a very broad prosternal process, no pubescence is apparent inside the front tibiæ, and, if the form were not almost exactly that of $H$. ferruginea Horn, the species might be referred elsewhere. The four species agree in having eleven-jointed antennæ with the second joint moderately and regularly enlarged, in having the last joint of the maxillary palpus moderately elongate, and in having the last ventral segment of all specimens curiously emarginate, the emargination having removed a narrow, semi-circular strip from the edge of the apex of the segment, leaving the actual apex unchanged in form but causing the sides to appear lobed or toothed. This character is variable from species to species, but the difficulty of describing it has rendered its use inadvisable at present. An attempt has been made to select only the more useful characters for mention in the descriptions, and to avoid the repetition of statements which have been made in the discussion.

For comparative purposes the key which precedes the descriptive portion of the paper has been constructed to include Helmis smithi Grouvelle, which I know only from the literature, and the two Texas species $H$. ccesa Lec. and $H$. ferruginea Horn, of which I have seen the type and authentic specimens, respectively, in the Museum of Comparative Zoölogy. I must express my thanks to Mr. Banks and the authorities of the museum for permitting me to examine these and many other specimens, and I must also thank Dr. Thomas Barbour and Dr. W. M. Wheeler for arranging my Cuban trip, and Mr. R. M. Grey and other friends at Soledad for helping to make my stay profitable and enjoyable.

Key: Cuban and related species.

1. Pronotum with a pair of sublateral, elevated carinæ paralleling the lateral margins; palpi pale; intercoxal portion of prosternum about half as wide as that of mesosternum.......2 
Pronotal disk without carinæ or definite impressions; palpi infuscate; intercoxal portion of prosternum nearly as wide as that of mesosternum...........Helmis simplex n. sp.

2. Pronotum strongly, transversely impressed at middle.. . 3

Pronotum longitudinally, not transversely, impressed... .4

3. Basal half of pronotum granulate, opaque. ..........

H. minima n. sp.

Pronotum entirely shining, not granulate; prothorax more narrowed at base; size a little larger; (Texas).........

H. ccesa Lec.

4. Elytra together nearly twice as long as wide; pronotum darker than elytra................. filiformis $\mathrm{n}$. sp. Elytra together about one and a half times as long as wide; pronotum never darker than elytra. .............5

5. Sublateral carinæ reaching anterior edge of pronotum...6

Sublateral carinæ abbreviated anteriorly; (Grenada).

H. smithi Grouv.

6. Ferrugineous; larger and proportionately broader; prothorax more narrowed at base; prosternum broader between the coxæ; (Texas)...................... ferruginea Horn.

Elytra usually slate-colored........H. quadrata n. sp.

\section{Helmis minima n. sp.}

Elongate, parallel, slightly depressed; piceous black, pronotum and front darker; abdomen, antennæ, legs, and labrum rufous; palpi pale yellow. Head moderately shining, faintly punctured and pubescent. Prothorax subquadrate, hardly as wide as long, slightly and regularly narrowed at apex and, very slightly, at base; sides otherwise nearly parallel; lateral margins finely crenate; disk with complete, transverse median impression, and with a pair of fine sublateral carinæ paralleling the side margins from base to apex, the distance between them being somewhat more than half the discal diameter; area before transverse impression shining, finely and sparsely pubescent; area behind impression dull, granulate. Elytra together a little less than twice as long as wide, very little wider than the thorax, the sides straight and very slightly divergent from just back of humeri to 
apical fourth; outer margin obsoletely crenate; disk sparsely punctured and pubescent; fifth interval with a fine carina from base nearly to apex; third interval not prominent at base; basal two thirds of four inner striæ represented by irregular series of punctures; a faint alutaceous sculpture visible near the larger ones. Length $1.3-1.4 \mathrm{~mm}$. Width $0.45 \mathrm{~mm}$. Holotype and three paratypes, Arimao River, Soledad, Cienfuegos, Cuba, Dec. $3,1926$.

One specimen, from the gravelly bank of a large brook, Nov. 24, has the head less shining, the thoracic and elytral margins more clearly crenate, and the elytral striæ longer; I have referred it to this species, but not as a paratype. With this exception, there seems to be no noteworthy variation. The form is almost exactly that of $H$. coesa Lec. from which it differs chiefly as indicated in the key. In this, as in all the following species, no sexual characters have been noted, and the size is really remarkably constant. The holotype, with the three of the other species, is in my private collection, and at least one paratype of each form described will be retained to lend to established students. Paratypes of all species will be deposited in the Museum of Comparative Zoölogy and the National Museum; of filiformis and simplex, in the American Museum.

\section{Helmis filiformis n. sp.}

Elongate, parallel, slightly depressed; dilute brown, with slaty tinges below and on elytral disk; head and pronotum dull black; antennæ, tarsi and palpi yellowish rufous. Head opaque, moderately punctate and pubescent. Prothorax subquadrate, about as long as wide, widest one third from base, slightly narrowed at base and apex; side margins slightly crenate; pronotum longitudinally impressed on median third, the impression indicated at base by a pair of minute carinæ; pronotum also with a pair of complete, sublateral carinæ paralleling the side margins anteriorly, but sinuate and slightly approaching the margins posteriorly, the distance between them being more than half the discal diameter; disk alutaceous or finely granulate, more distinctly so posteriorly, sparsely punctate and pubescent; elytra 
together nearly twice as long as wide, very little wider than the thorax, with the margins straight and very slightly divergent from just back of the humeri to apical fourth; outer margin finely crenate; fifth and seventh intervals elevated to about apical fourth; third interval more prominent basally than second or fourth; four inner striæ represented by stripes of irregular, dense alutation, obsolete on apical fourth; disk dull, sparsely pubescent. Length $1.8-1.9 \mathrm{~mm}$. Width $0.6 \mathrm{~mm}$. Holotype and six paratypes with same data as preceding species. Two paratypes from same locality, Oct. 19.

There is some variation in the degree of infuscation of the elytra. The general habitus is that of the preceding species, though perhaps a trifle more elongate.

\section{Helmis quadrata n. sp.}

Moderately stout, subparallel; slate-gray, abdomen and particularly pronotum with a reddish brick-colored tinge; tarsi and antennæ rufous; palpi yellowish rufous. Head dull, with small scattered black granules. Prothorax subquadrate, barely wider than long, widest about a third from base; slightly narrowed behind, more narrowed in front; lateral margins crenate; pronotum with a median longitudinal groove from base nearly to apex, the groove limited by two short carinæ at base; pronotum also with a pair of complete, sublateral carinæ parallel with the sides in the apical half but sinuate and slightly approaching the margins toward the base; distance between carinæ more than half the discal diameter; disk dull, finely and sparsely pubescent, not evidently granulate. Elytra together about a half longer than wide, a little broader than the thorax; margins inconspicuously crenate; intervals five and seven with granulate, elevated costæ reaching to about apical fourth; third interval prominent at base; four inner striæ represented by narrow, irregular grooves; first at least indicated to apex; disk dull, finely and sparsely pubescent. Length $1.9-2.1 \mathrm{~mm}$. Width $0.8-0.9$ $\mathrm{mm}$. Holotype and four paratypes with same data as H. minima.

This species, too, is very constant in essential characters. In one specimen the reddish shade of the pronotum is diffused 
over the elytra, enhancing the resemblance to ferruginea, from which it differs principally as indicated in the key. The prosternum seems to be slightly broader between the coxæ in that species, and the median groove of the pronotum is much less distinct at base.

\section{Helmis simplex n. sp.}

Moderately stout, subparallel; dull black, with a pinkishgray tinge below; tarsi, trochanters, and antennæ rufous, latter a little paler toward the base; palpi infuscate. Head dull, with scattered dead-black granules on a uniformly muddy background. Pronotum barely wider than long; sides subparallel, slightly more narrowed in front than behind; disk regularly convex, without carinæ, and with the barest trace of a longitudinal impression at base; disk evenly, sparsely, and finely punctate and pubescent. Elytra together about one half longer than wide; four inner striæ almost completely obsolete; third interval not prominent; disk finely and sparsely pubescent, opaque, smooth near the suture, with several rows of granules externally the most prominent on the seventh interval. Length 1.9-2.0 mm. Width $0.8 \mathrm{~mm}$. Holotype and twelve paratypes with same data as $H$. minima.

The most distinct and perhaps the most constant of the four species described. The affinities are probably toward $H$. quadrata, the general form of which is closely imitated, but the relationship is not very close in other ways.

After the preceding portion of the paper had been completed, a small lot of West Indian Helmis was received for study through the kindness of the authorities of the United States National Museum. Of the three species involved, one, represented by three specimens labeled "Grenada, W. I., Aug. Busch Collector" is undoubtedly H. smithi Grouvelle, described from the same island in 1898 (Notes fr. Leyden Mus., XX, p. 47). This insect is closely related to $H$. ferruginea Horn, but is separable as previously indicated. The difference in the thoracic carinæ is not very marked, but is supplemented, as Grouvelle said, by one in the median, longitudinal groove of the pronotum, 
which is longer in smithi. The two other species are both from Jamaica collected by H. G. Hubbard, and are very close to the species described above as minima and filiformis, of which they seem to be at best no more than geographical varieties. The form near minima is represented by a single specimen, $1.5 \mathrm{~mm}$. long, which seems almost exactly typical in shape and sculpture, though the latter is slightly obscured; that near filiformis, however, seems subspecifically distinct.

\section{Helmis filiformis jamaicensis n. subsp.}

Almost precisely as in typical filiformis except as follows: the color above is practically uniform, ranging from dull rufous in the holotype to piceous in the darker paratype. In the latter there are vague rufous areas near the humeri, but these do not suggest the straw-colored elytral ground of typical filiformis. The median longitudinal groove of the pronotum is slightly finer and not as abbreviated as in the Cuban form. The size is slightly greater, the three specimens being between 1.9 and 2.0 $\mathrm{mm}$. in length. The holotype and two paratypes belong to the collection of the National Museum. The type is No. 40350 in the collection of the U. S. National Museum. 

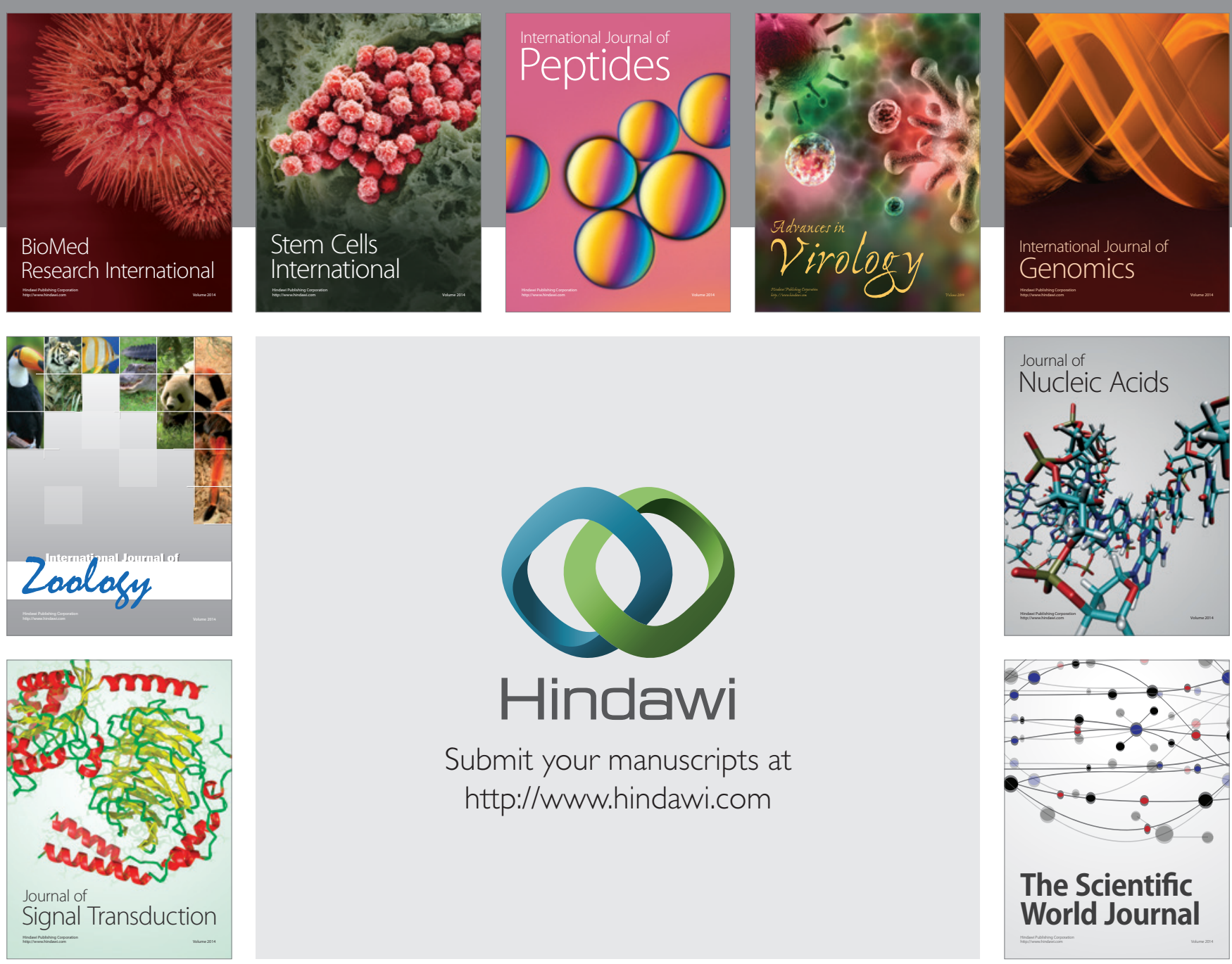

Submit your manuscripts at

http://www.hindawi.com
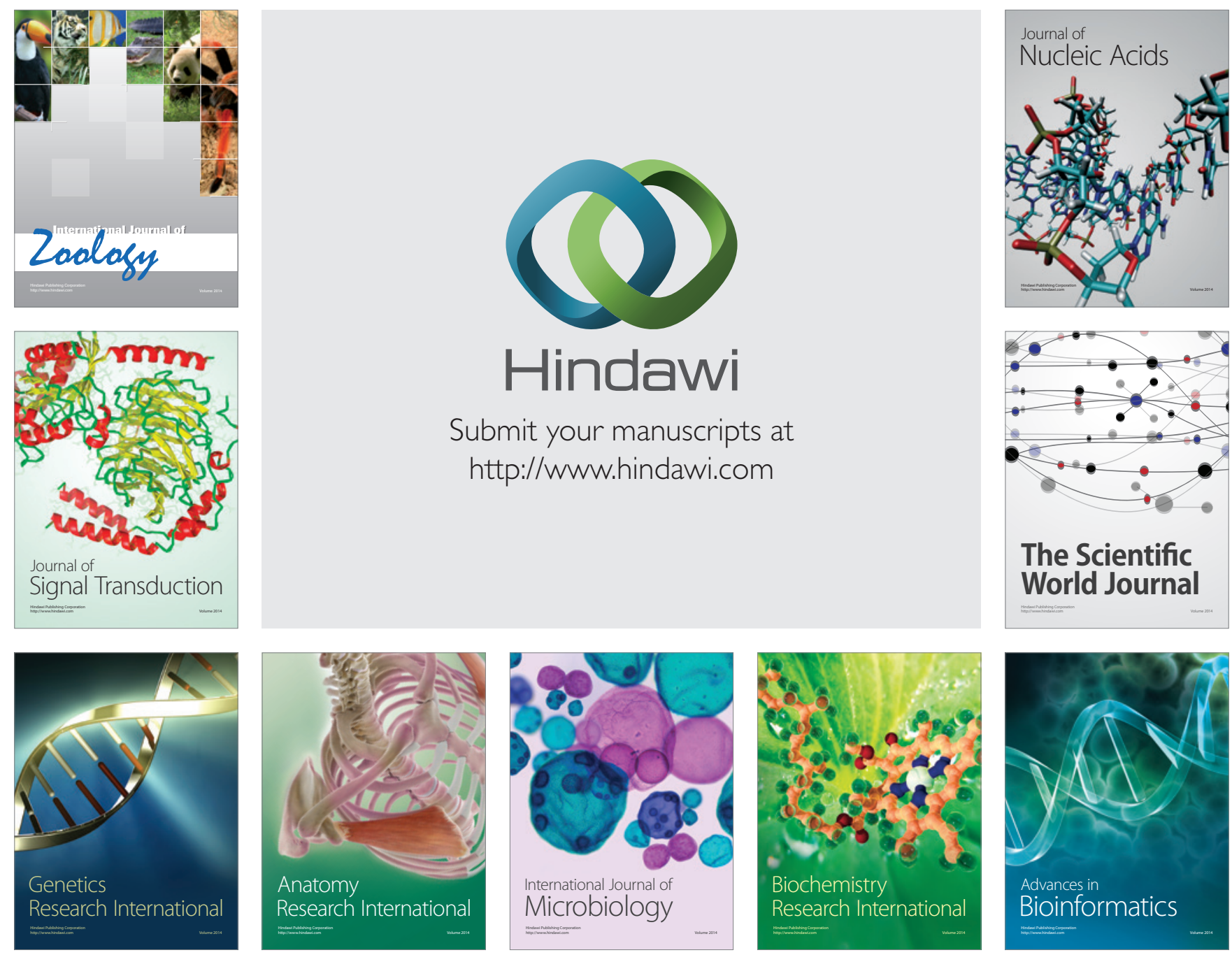

The Scientific World Journal
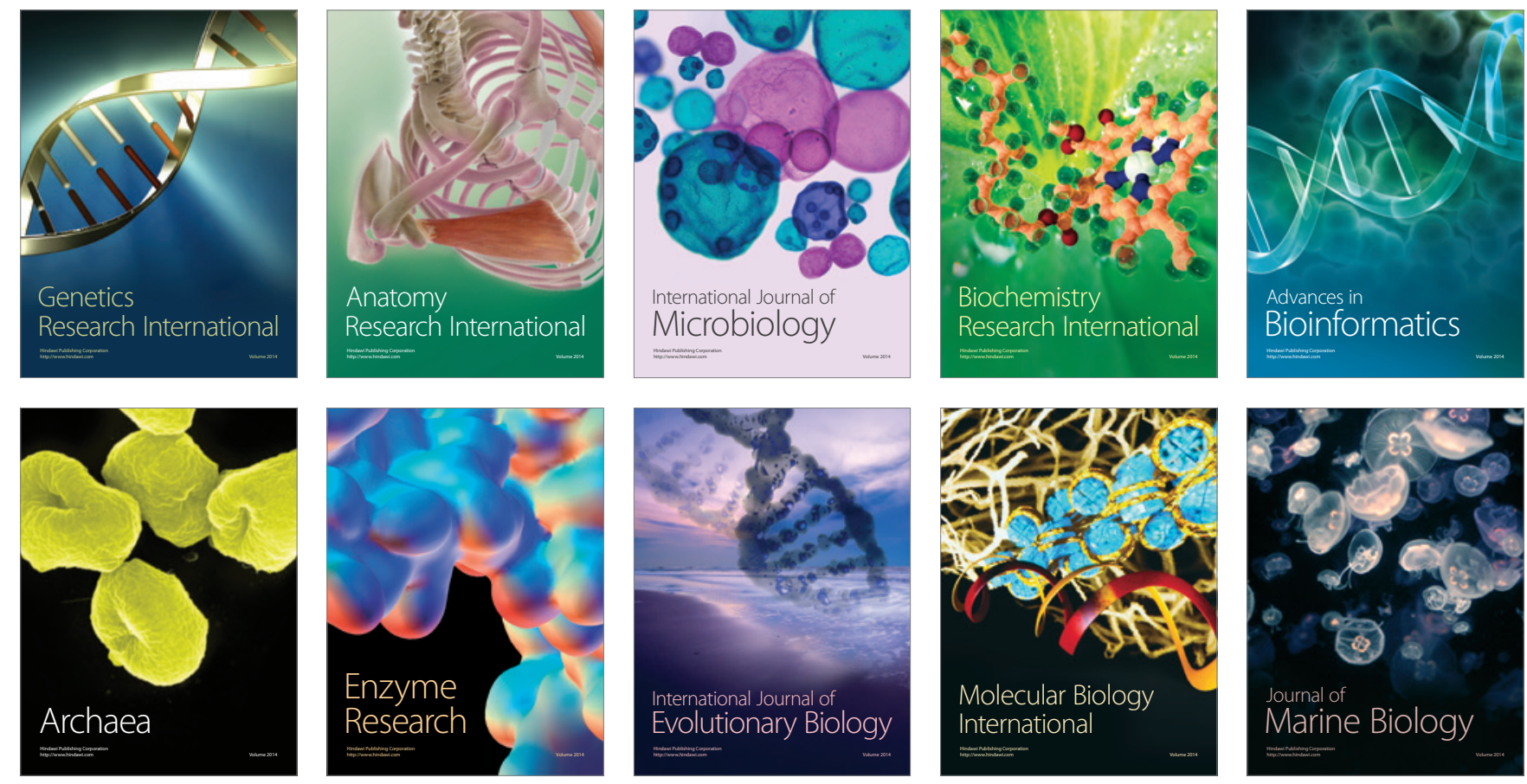